\section{Brandeis $\mid$ usear}

brandeis.edu/j-caste
CASTE: A Global Journal on Social Exclusion

Vol. 2 No. I pp. I53-173

April 2021

ISSN 2639-4928

DOI: $10.26812 /$ caste.v2i1.264

\title{
Caste, Reading-habits and the Incomplete Project of Indian Democracy
}

\author{
Subro Saha'
}

\begin{abstract}
Emphasizing on the functioning of caste as embodiment, this paper attempts to show how the internalization of dominant caste-based framework(s) shapes our habits of thinking which include epistemological and pedagogical orientations as well. The paper briefly traces how such frameworks have settled through historical shifts and shaped dominant imagination of the nation' that has appropriated caste-system as its essence. To show such making of a dominant framework of caste and Hindu-nation, the paper briefly turns towards nineteenth century Bengal, both as a reminder of the many forms of dwelling within vernacular communities and how such multiplicities came to be reduced within a hegemonic framework of majoritarian Hindunation. Such making, the paper submits, shapes a doubleness of the decolonial project of nation-making which finds its paradoxical settlement within the postcolonial democratic framework through the embodiment of the majoritarian (casteist) framework of Hindu-nation. The paper, therefore, examines how such problems of embodiment become an infrastructural problem that haunt one's everyday imagination, and therefore calls for creation of infrastructures that can enable a training of imagination to unlearn such embodied frameworks of segregation. As one such small ontoepistemological possibility, the paper examines the role of aesthetic education and its suspending potentials.
\end{abstract}

\section{Keywords}

caste, embodiment, nation, equality, reading

\footnotetext{
'Assistant Professor, Amity Institute of English Studies and Research, Amity University, Kolkata; International PhD Fellow, Institute for Cultural Inquiry, Utrecht University, Netherlands E-mail:subhrol29@gmail.com/s.saha@uu.nl
} 


\section{Introduction}

The persistence of caste within the democratic framework is a continuous reminder of the failure to make possible an infrastructural framework of equality that the dawn of democracy had promised. The moment of decolonization and the nation-making project shared the common challenge - the making of a democratic infrastructure that would bring people together, 'equally.' However the continuity of everyday caste prejudices and violence is a grim reminder of the incompleteness of that project. The persistence of caste within postcoloniality is a testimony of the layered historical sedimentations of caste within modernity through which the postcolonial conceptualizations of 'national' identity remain largely determined (in terms of a hegemonic framework of Hindu religion and nationality). In this scenario, a situation has historically unfolded through generations, which is too deeply embedded to get rid of easily. Thus, addressing caste through an exclusive empirical lens remains inadequate to examine the roots of the problem especially because the concept of caste is after all an 'idea' that finds its material presence through embodiment. One can recall here the division between 'means' and 'end' that Ambedkar had emphasized in his essay Castes in India: Their mechanism, genesis and development. Though the essay pointed at the role of endogamy and surplus body in the sustenance and regulation of caste, we can extend the 'means' and 'end' division to realize that even endogamy is an embodied 'idea' that one practises in their material existence, while simultaneously the circulation of practice cements the idea as 'truth.' Such materialization, therefore, acquires an auto-generative circulation that doesn't depend on any singular framework for its own functioning, but instead determines the functioning of all other frameworks as, for example, the autogenerative circulation and domination of capital and how it shapes all other domains. Such autogenerative circulations of caste can be called, using Anirban Das's (2017) views, a materialization without the messianicity of 'matter' (p. 29). Talking about the functioning of nation-time, Das reminds of the difference between 'messianicity' and 'messianism' that Derrida draws referring to Benjamin's views: 'Messianism remains linked to "the memory of a determinate historical revelation" and "a relatively determinate messiah-figure", whereas messianicity excludes these determinations and constitutes itself in a different register where messianicity can function without messianism (Ibid). The functioning of caste, I submit, also involves a similar messianicity that doesn't rely on any singular determining register of messianism. Such materialization of caste reminds us continuously of the nonlinear historical sedimentations of ideas into dispersed forms of everyday material existence through embodiments and corporeal figurations. It is this aspect of caste as the organizing principle and embodiment of a certain dominant outlook (and rejection of other viewpoints) that gets fused through historical shifts as the 'essence' of Hinduism, and countering caste therefore, essentially becomes a question of training imagination that can re-organize such alternative histories/viewpoints. Although the sedimentation of caste hierarchies has unfolded and continued historically yet such unfolding has produced waves of divergence and disruption to such hierarchies, which either lost their momentum or got appropriated in various junctures of history within the hegemonic framework of the hierarchical caste-based social structure. As a result, caste has continued to thrive notwithstanding the democratic framework. To examine such continuity and survival of caste it becomes essential to analyze the question of embodiment that characterizes the habits of thinking. For that purpose, I attempt, in this paper, to trace briefly the doubleness of the nation-making project that started unfolding 
from nineteenth century and paradoxically found its settlement within postcoloniality. What enables the survival of caste, I submit, is this spectre of doubleness haunting our imagination. Extending Sudipta Kaviraj's (2003) views on the role of an ideological 'principle of organization' in the making of a dominant version of Bangla literature in the nineteenth century (p. 503), I attempt here to show how such an ideological organizing principle has continued to shape the persistence of caste by linking it with a hegemonic concept of 'Hindu' nation. To trace such a making, I briefly turn to the histories of nineteenth century Bengal and the emergence of an early framework of majoritarian Hindu nationalism (as one slice among multiple similar forms of making within other vernacular communities of colonial India), ${ }^{1}$ the unresolved tensions within which resonate today in recurring forms of embodied perspectives. However, as emphasized already, engaging with a slice of vernacular colonial history here offers a reminder of the multiple forms of dwelling within a community which otherwise is often reduced within a singular dominant framework of the nation. The point to focus thereby is an underlying logic of reductionism that tends to reduce one's imagination of democracy (as well as identity) in terms of a dominant framework of Hindu-nation and its embodied caste hierarchies. Engaging with the question of caste today, therefore, calls for a cautionary awareness of the habits of thinking, and it is with such awareness that one needs to rethink what actually the concept of 'annihilation' called for. Such exorcism of the ghost of caste that determines one's very act of thinking requires countering a deep problem of imagination that continuously shapes one's material actions and existence. In other words, the historical unfolding of caste and linking it with a hegemonic spiritual as well as national duty eclipses one's very capacity to think, and that's why, I submit, countering such a deep-seated problem requires creating infrastructures for training of an imagination that can counter the existing habits of caste-based imaginations. The paper pushes towards a re-conceptualization of such possibilities not as some messianic promise but as an ethico-political necessity that one needs to keep cultivating both within the individual as well as within the community; that is where the paper aims to reflect, as one possible way among others, on the suspending and transforming capacities of aesthetic education.

\section{Question of Difference or the Question of Appropriation: Caste and the Making of the Historical-sense}

Though the problem of training the habits of thinking goes back to the Vedic times, yet to start with a point of reference, one can take the nineteenth century and the making of the nationalist consciousness as an example of how caste at different junctures of history came to be organized as the 'essence' of Hinduism and Hindunation, the embodied spectres of which continuously haunts the postcolonial nation. The making of the organized framework of a dominant Hindu nationalism in the early nineteenth century required essentially an ideological organizing principle that would simultaneously perform two tasks - (i) resolve and appropriate contradictions, and (ii) dismiss the irresolvable tensions in a way that didn't affect the framework. This

${ }^{1}$ For example, the works on Marathi, Kannada or Odiya communities by many scholars have traced similar framing of caste despite eruption of protests and divergences. For further details, see Dalit Literatures in India (2016) edited by Joshil K. Abraham and Judith Misrahi-Barak, and "Dalit Writing: an Introduction" and "Introduction: Kerala" by K. Satyanarayana and Susie Tharu in The Exercise of Freedom: An Introduction to Dalit Writing (2013). Also see, Sheldon Pollock (Ed.), Literary Cultures in History: Reconstructions from South Asia. 
was done through the constitution and separation of conceptual boundaries between what is 'interior' and 'exterior.' It was through the making of such 'organizing principle' that the Persian and Musalmani elements in Bangla language were excluded as 'foreign,' and an added emphasis was brought to establish the affinities between Bangla and Sanskrit, thereby constituting and elevating a selected version of 'national' character by paradoxically continuing the Orientalist model of sanskritization of Indian past (Kaviraj, 2003). This reminds us of the politics of constituting singular 'national' frameworks through systematic exclusions that get buried under the weight of changing times and over the corpses of which new national ideals are framed. As an early reminder of such exclusion, one may turn towards the heterodox or nastika systems (systems which have not relied on metaphysical concepts like afterlife, sin etc., but had emphasized on the centrality of human body and physical reality) of ancient Indian philosophy which are usually avoided to emphasize the centrality of Vedic thought and therefore, to establish uncritically the spiritual links between Hinduism and caste hierarchies. In this regard, and among two such early examples of the heterodox trends, mentions may be made of lokayata and mimansa, which keep on reminding us of the impossibility of reducing ancient Indian past within any fixed singular framework. As highlighted by Debiprasad Chattopadhyay (1959), Ramkrishna Bhattacharya (2011), Romila Thapar (2019), and many others, even in such early times, the establishment of a hegemonic worldview or 'idea' always mutually depended on material concerns and power-structures of a society that had direct links with the enjoyment of privileges and surplus products. At different junctures of history, we see how there had been an underlying tendency to think of Hinduism only through the Vedic hegemony; disregarding the diverse heterodox trends characterizing ancient Indian past, all of which not always emphasized the centrality of caste. Apart from lokayata and mimansa, traces of such heterodox systems of thought and their eventual dismissal/appropriation can also be found in the later times; for example, the Bhakti cult of Chaitanya, and sahajiya vaishnavism in sixteenth and seventeenth centuries Bengal. This refers to a time when the organized identification of a nationalist Hindu hegemony was yet to emerge and the Mughal king and Brahmin priests worked together in maintaining the socio-political hierarchies, and it is around such time of the Bengal Sultan Allauddin Hussain Shah's reign that Chaitanya used to perform his kirtans publicly disregarding any caste-barrier which was a point of serious concern for the orthodox sections. Though Chaitanya never attempted any direct attack on the varnashram dharma ${ }^{2}$ (this term can be roughly translated as a religious duty to essentially maintain and follow the caste hierarchies and its associated divisions of labour), yet Chaitanya's movement had serious subversive implications since the congregational singing, offered unknowingly a sense of dissent for the Brahminical hegemony which was soon appropriated through the collective forces of Brahminical dominance and emergent ideology of Hindu nationalism. After Chaitanya's death, though his disciple Nityananda and his son Birabhadra continued preaching devotion through dasyabhava (the mood of being a servant of God) and sakhyabhava (the mood of being a lover of God) among the lower castes, the practice of Vaishnavism in Bengal soon started leaning towards the Vedic and Upanishadic traditions for getting Brahminical and royal support. Between 1610 and 1620, at the Kheturi festival

${ }^{2}$ Sekhar Sengupta notes one such example, when on one occasion his low caste disciple Haridas, a convert from Islam, opted to dine separately, for fear of offending other high caste disciples, and Chaitanya did not object to it (Bandyopadhyay, 2004, p. 81). 
organized under the patronage of Raja Santosh Datta, this task of 'tying' Bengal Vaishnavism with 'the orthodox traditions of Indian religion' was accomplished by the sada or six Goswamis of Vrindaban (Bandyopadhyay 2004, p. 81). Similarly, the Sahajiya Vaishnavism tradition, which was directly influenced by Buddhist tantric traditions, refused to believe in any transcendental views except the attainment of bliss through corporeal sensations. Though later both these trends were incorporated within a dominant version of Vaishnavism that accepted varnashram dharma and ritualism, yet they remind us simultaneously of the continuity of heterodox religious practices within Hinduism (especially tantra and dehavad, which are two of the heterodox trends emphasizing on the primacy of the physical body) as well as their appropriation or rejection by the Vedic hegemony within Hinduism. These few examples can be seen as crucial reminders of the historical sedimentation of a dominant framework of Vedic Hinduism that takes caste as its essence. It is the embodiment of this hegemonic framework that has continued to captivate the general imagination of Hinduism in exclusive ways by either appropriating different theological positions or by dismissing them as heretic, licentious, or immoral.

The turn of the nineteenth century posed the urgency for framing a nationalist ideology that would enable organizing the masses under one conceptual umbrella. Therefore, a reevaluation of the past and tradition was essential. Here we see a selective re-assertion of the Vedic and Upanishadic traditions, interestingly not the heterodox or nastika systems of thoughts, even though orientalists like Max-Muller (1899) and Colebrooke (1858) repeatedly emphasized on the essentially pluralistic character of Hinduism. The reason for such selection was the reassertion of a certain framework of spirituality and the linking of it with the duty of the individual as his essential (Hindu and varnashram) 'dharma. ${ }^{3}$ By the time we reach mid- nineteenth century, the task of the native intellectual was therefore to enable a form of synthesis between a binary that exposure to western ideas has brought within the native society: between tradition and modernity, scientific rationality and religion, spirituality and material prosperity (Chatterjee 1993, pp. 95-116). Caste in such making always operated as an anomaly, as the western ideals of equality, liberty, and fraternity stood absolutely against the logic of hierarchy and predetermination that caste stood for, and therefore newer ways of justifying caste-system were sought. In such a situation we can understand that not only the contemporary interpretations of historical lineages were read through a specific organizing framework, even the intellectual-function of the contemporary Bengali intellectuals was determined through a similar embodied organizing principle, dismissing intellectuals who were pushing towards rejection of caste-system as either heretic (like Derozio) or westernized (like Akshay Kumar Dutta). ${ }^{4}$ Even some would

\footnotetext{
${ }^{3}$ The dharma premised on varna system and control stands for oppression; therefore Ambedkar emphasized on the Buddhist concept of dhamma to highlight a type of religion that doesn't necessarily rely on any dominating, prohibitory religious force. In the recent years, Ambedkar's views on Buddhist dhamma have been emphasized by scholars to emphasize on different aspects of religion beyond the oppressive varnashram dharma. For example, Kumar (2015) emphasizes on Ambedkar's views on sunyata and loss of the self as developed from the Buddhist views of dhamma to emphasize on Ambedkar's vision of a radical equality that doesn't depend on any singular universal religion. Guru and Sarrukai (2019) emphasize on Ambedkar's ideas of maitryi (empathy) to emphasize on a bonding of beings that caste prevents.

${ }^{4}$ Derozio was trying to educate his students of Hindu College in a spirit of radical rationalism (being influenced by Bacon, Spinoza, Kant, Paine and others) that refuses to believe in any
} 
read western ideas only for linking them with the caste-system; for example, Jogendra Chandra Ghosh did by using Comtean positivism for justifying caste hierarchies and Brahmin rule (Flora, 1993). The colonial contact and circulation of capital, along with exposure to western education, had brought significant changes within the existing caste-based occupations enabling many of the lower caste groups to rise economically with newer occupational avenues (Mukherjee, 1977). Because of such circulation of capital many small traders, brokers, and junior administrators (like pykars, dallals, gomasthas, munshis, banyas, and dewans) rose in their class positions despite coming from lower castes. As such, many seths (money-lenders) and banyas (businessmen) were emerging from lower castes who were otherwise supposed to continue in castebased hereditary professions as weavers, farmers, fishermen, etc. Grish Chunder Ghose in his biographical lecture on Ram Doolal Dey thus directly emphasizes that by the nineteenth century there was an aristocracy coming from the middle (and often even lower) castes that were not born but made (emphasis added). In 1795, Colebrook had already noticed that every profession, with a few exceptions, was open to 'every description of persons' and 'Brahmins are often employed in the most servile office and the Sudras often elevated to situations of respectability and importance' (1795, p. 133). As Pradip Sinha (1965) points, the rapid changes within the early ninteenth century colonial Calcutta regarding occupational modalities and caste practices were creating an impression as if soon the entire caste-system might be dissolved in the metropolis (p. 4). Added to this social mobility brought by the circulation of the colonial capital, was the increasing number of conversions by poor untouchable castes who, to escape the tyranny of caste discrimination within Hinduism, were turning towards Christianity or Islam. Therefore, through different phases of such making of the nationalist project in colonial Calcutta, we see various attempts to modify and appropriate caste (as an essential element of Hindu tradition) with modernity, and this was done by linking 'jati' (genus) with a collective framework of 'jatiya' or national, and to establish such linking the same orientalist philological explanations of the Aryan race were used. However, quite paradoxically, it is using the same orientalist philological explanations of the Aryan race and original religion of man (especially the views by the German Romantics, William Jones, Max Muller, and Colebrooke) ${ }^{5}$ that Akshay Kumar Dutta in his book The Religious Sects of India (Bharote Upashok Soprodaye) was trying to counter caste discriminations and Hindu-Muslim tensions by trying to remind a shared commonness of all religions on the one hand and the diverse inclusive heterodox systems of religious practices within Hinduism that had coexisted since ancient times on the other. Though such an approach to counter the caste-system in nineteenth century was very rare, yet the importance of such limited attempts cannot be ignored entirely. However, the problem, as it has been asserted already, was with a mass-embodiment which by that time had successfully internalized an exclusive view of Hindu-nation with caste-system as its essence. Therefore, such attempts as by

dogmatism or superstition and therefore accepting caste was impossible for such students. Dutta on the other hand was trying to prove the historical inconsistencies, irrationalism, and fabrications of caste-system; instead trying to emphasize (being heavily influenced by the German philological and Indological emphasis on universal religion) on a unified religion for all.

${ }^{5}$ For further details on the role of German Romanticism (especially the philological affinities between Sanskrit and Western classical languages) in the shaping of the Aryan myth and linking it with caste, which further shaped the German Indological and French Orientalist views, see Figueira's Aryans, Jews, Brahmins : Theorizing Authority through Myths of Identity (2002). 
Akshay Kumar Dutta could only be seen as the product of a native intellect that has been westernized (or let's say, corrupted) entirely to question caste-system. As Sekhar Bandyopadhyay (2004) reminds, nineteenth century Bengal marked a crucial phase whereby the volatility of the concept of 'jati' (genus) within pre-colonial systems of social-organization underwent a double reduction: first under the lens of colonial anthropology, and secondly by framing it within a category of 'jatiya' (national). This constituted a central move towards the making of the Hindu nationalism whereby violating one's 'jati' got linked with violating the 'jatiya' or national responsibility. Therefore, though sati $^{6}$ and widow-remarriage were often debated between the liberals and orthodox sections, the thinking of absolute dissolution of caste was unthinkable for both sections due to the embodied belief that one's caste stood for one's lineage and roots; thus to give away caste meant giving away one's national identity, community, and religion (a view that is cherished by many even today). Those elites who rejected caste hierarchies; for example, members of the Young Bengal group who openly consumed beef and wine, were dismissed as corrupt and immoral (Chaudhuri, 2012). Rammohun Roy, therefore, would never dine openly with British officials and was even accompanied by a Brahmin cook duing his visit to England to ensure that no one raised a question on the purity of his caste (Mukherjee, 1977, p. 46-47). However, those elites who violated caste boundaries could also be appropriated within the caste order by paying handsome amounts to the powerful Brahmin communities, which led a contemporary elite Ramdoolal Dey to even declare that his caste was in his 'cash box' (Bandyopadhyay, 2004, p. 54). Violation of caste boundaries, therefore, was seen as a very serious crime, and regulatory bodies led by upper-caste elites (such as Jatimala Cutcheries or different Sabhas and Samaj) were created to regulate such transgressions. As caste was a deeply embodied aspect of every individual psyche, something that had been ingrained within an individual since birth by the community, household, and ancestry, the emerging urban spaces of Calcutta had embodied castesystem through tricky negotiations with modernity, a kind of a curious synthesis wherein modernity, science, and rationality were welcomed, but caste-system was also added with modifications to fit into the changing times. One such aspect of the continuity of the caste-system was the 'communal organization of household' where the rural, traditional, ancestral values (including obviously the caste order and rituals) were projected within the conceptualization of 'home' and domesticity of urban life. Therefore, oscillating between external social changes and embodied perspectives, western modernity and native traditions; the English-educated elites of urban Calcutta welcomed western idea(1)s but were not ready to forego their traditional customs, caste regulations, and practices. Consequently, the native intellectual's thoughts would often suffer this doubleness characterizing a colonial city:

If he had really come into close contact with western ideas, he led a two-fold life, his intellectual life that was fed by memories of Byron and Shelley, of Mill, Macaulay, and Huxley; and his family life fed by domestic affections and protected from external shocks by an indulgent and amused compliance with the forms and rigours of old social order. (Sinha 1965, p. 12)

By the late nineteenth century, while in the newly formed elite urban spaces of colonial Calcutta circulation and accumulation of capital was a determining factor in shaping

${ }^{6}$ The practice of widow-immolation on the husband's pyre. 
caste regulations and transgressions, in suburban areas and villages lower-caste protests were also emerging strongly. For example, the Balahadi sect among the Hadis of Nadia district, the Koch/Rajbansis of North Bengal, the Bhuimalis of Mymensingh district among many others contained the possibilities of constituting an alternate domain of politics but were later contained within the framework of a hegemonic Hindu nationalism (Chatterjee, 1993; Bandyopadhyay, 1997). However, such eruption of contradictions within the established caste order was a serious concern in the making of a majoritarian Hindu nationalism that can simultaneously resist the colonial as well as Muslim influence. Therefore, while the Persian, Islamic, and colonial influences in Indian culture were construed and dismissed as 'foreign' elements, the caste question was dismissed as an 'internal' religious tension and not one of any serious political concern. Since caste couldn't be dismissed as a 'foreign' element, unlike the Muslim and colonizer question, it continued to operate as an internal contradiction and anomaly within the established framework of Hindu nationalism.

By the turn of the twentieth century, though the appropriation of the caste problem was attempted by denying it a political status, the depressed classes movement continuously problematized the emergent nationalist assurances. Therefore, when Srinath Datta argued in an article in Nabyabharat that in the Congress every caste from Brahmin to Bagdi, or from Kayastha to Keora had equal rights, the hollowness of such words was very clear (Bandyopadhyay 2004, p. 66). Scientist Prafulla Chandra Ray too dismissed the call for political reform of caste as unnecessary by asserting that there was no fear of Brahmin rule in a future nation-state, and similarly, Meghnad Saha and grammarian Madhusudan Kabyabyakarantirtha also emphasized the caste question as a social problem and not a political one (Ibid, p. 67). In fact, within many of these early twentieth century intellectuals, there was a deeply held trust in a re-imagined caste system representing a moral social order that differentiated India from the modern western models of social organization. In such a scenario, the caste question was continuously refused to be taken as an urgent political problem, and whenever it was considered, the central concern remained something else. For example, one of the central concerns during the phase of decolonization was the fear of losing the Hindu identity to a Muslim majoritarian nation-state. This was a fear that was earlier expressed in the nineteenth century by the Bengali writer Iswar Gupta as western education was seen as a corrupting influence on the caste order thereby corrupting Hindu identity and the nation itself:

... यহেতে হনিদুুকালজেরে হন্দিত্ব আর রক্যা হয় না। এই কালজেরে (শাখা) যাহা হার সাহবেরে

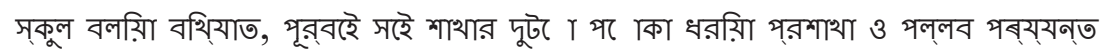
নষ্ট করতিছে, তাঁহার একটী প( াকা ঈশুর থ( াকা, একটী প( াকা মহম্মদরে থ( াকা। উকত্ত

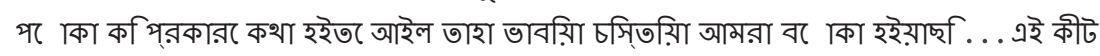
ইহার পর ভস্ম কীট হইয়া মূল শুদৃধ ধ্বংস করবির (Editorial dated 11 February 1853; Bengali year 11 Falgun 1259) (Ghosh 1955, p. 337)

[... the Hindutva of Hindu College is under threat. A branch of this college, which is known as Hare Saheb's school, is already affected by two insects which are destroying it slowly; one of that insect is an offspring of Christ, another one of Muhammad. We have wasted our time thinking about the history of these insects ... these insects might later destroy the entire roots of the tree] (translation mine) 
These lines as if resonate directly with many arguments that we hear today through which similar fear is continuously instilled among common people. Similar fear was expressed also in the twentieth century with the publication of books like U.N. Mukherjee's Hindu-The Dying Race (1912), Swami Shraddhanand's Hindu Sangthan: Saviour of the Dying Race (1926), and the formation of Hindu Mahasabha in 1933. While we see echoes of similar fears continuously fuelling the narrative of Hindutva, we need to realize how deeply embodied such fear is within the imagination of the common people to repeat almost similar concerns even today. Analyzing the reasons for the survival of caste therefore calls for analyzing deeply the socio-genic becomings of caste that not only shapes the ontogenic identifications of the individual but also determines one's historical sense. Quite obviously then, as Sekhar Bandyopadhyay (2004) points, caste functions as a hegemony that organizes one's sense of spatiotemporal belongingness by determining what is to be included and excluded.

\section{Theory or Practice, Epistemology or Experience: Caste and the embodied habits of reading}

While talking about caste as hegemony, we can here briefly turn towards some of the points Gramsci had made about the intellectual-function in a capitalist society which, in the case of caste, enables us to engage with the question of embodied perspectives and their role in shaping the intellectual functions. We may re-member here Gramsci's cautionary reminder that though the intellectual feels themselves, their views and functioning as autonomous, none of these is dissociated from the social relations and historical processes shaping them and their 'ideas.' As Gramsci reminds us, the shaping of the intellectual and intellectual-functions remain directly linked with the significant social group one belongs to since the ideas of such group directly shape the ideas of the intellectual and his/her intellectual-function (be it as a continuation or opposition). The intellectual, identifying with some group or ideology, tries to assimilate himself/herself to that ideology, or develops it further by extending it and its function, thereby also assimilating them and increasing their function concerning that ideology. In the case of a colonial city, because of the splitting of society into natives (insiders) and colonizers (foreigners/outsiders), the intellectual too finds himself/herself caught in the midst of contesting ideologies and social groups from which they must make a choice and identify themselves and their intellectual-function accordingly. He/She, therefore, interprets their social relations and ideologies and makes their identifications accordingly; based on which they further connect with their textual, historical, and cultural readings and identifications to strengthen and situate them according to the identified intellectual-function. In the context of colonial Bengal, the turn of the nineteenth century had already posed the urgency for framing a nationalist ideology that would enable organizing the masses under one conceptual umbrella, and the intellectual-function therefore was expected to offer guidance towards such making. However, since colonial-contact exposed the native minds to diverse forms of readings, the intellectual-function too was operating with diverse perspectives on shaping the society and their reading habits. The increasing circulation of print was enabling the native intellectuals to directly connect with diverse textual readings: Thus while including print and circulation of ancient Indian texts (both in Sanskrit and different vernacular translations) like Dharmashashtras, Manusmriti, Upanishads, Ramayana, Mahabharata, and so on, it also enabled direct encounter 
with the European ideas of Greek philosophies, enlightenment, humanism, positivism, romanticism and the contemporary viewpoints on French Revolution. In such a situation, the native intellectuals with their diverse ideological identifications wanted to extend their thoughts by making the common masses follow similar ideas. Thereby nineteenth century Bengal was witnessing a huge rise in print circulation (ranging from bilingual newspapers, literary compositions, reading and debate clubs, to pamphlets, and so on) through which they attempted to train the masses in certain forms of reading habits which could help them extend their intellectual-function by producing a mass that too supported and thought within similar ideological frameworks. However, as already emphasized, such exposure wasn't able to create a systematic radical rejection of caste for that had been internalized as a form of losing one's native identity (since caste was embodied as directly associated with one's lineage, religion, and roots), and a similar view was expressed by nineteenth century Bengali intellectual Bhudev Mukhopadhyay who declined a dinner invitation by a European friend, saying:

Dining with you would have been an act of violation of our social code ... We have lost our political freedom, our religion is under your attack ... What else have we got to give us a sense of pride or maintain our (cultural) individuality? You may call it superstition or a social code, the system of caste and codes of ritual conduct are all that we know now. These I cannot abandon. (Ganguly 2005, p. 01)

Thus, instead of rejecting caste as discriminatory, the native intellectuals felt it essential to synthesize it with western modernity and science, and this characterized the historical making of a doubleness through which not only caste found its settlements within the modern 'nation' but continues to shape the postcolonial democratic sociality till date. A specific framework of Hinduism that had dominated people's imagination for so many generations cannot change itself suddenly; therefore at different junctures of historical change such embodied views (for example, that caste is the 'essence' of Hinduism) have found its settlements in newer ways, be it in the shaping of the idea of 'nation' or one's identity. That however doesn't mean that history has not produced contradictions and oppositions to such hegemonic framework of caste, but the problem lies with the mass embodiment of a framework that had at different junctures either punctured those oppositions, or have weakened and appropriated them. As Sumanta Bandopadhyay points, such historical continuity of the appropriation of what is otherwise different from the dominant hegemony of Vedic Hinduism offers us certain crucial reminders in the present times, when one can find similar attempts to appropriate 'dissent' within certain dominant frameworks of understanding (Bandopadhyay 2008, p. 37). However, in such context as in the present times, where we see the continuity of linking caste with India's spiritual past and Hinduism, we need to remember the continuing historical sedimentation of such embodied views since nineteenth century. By asserting that while I attempt briefly to dislocate the recent claims of making a majoritarian Hindunation as a thought that is not immediately new, it simultaneously offers a cautionary reminder how immediately available solutions may not be able to get rid of a problem that had unfolded with long continuing historicity, a fact that Ambedkar was deeply aware of when he asserted: 'I may seem hard for Manu, but I am sure my force is not strong enough to kill his ghost. He lives like a disembodied spirit, and is appealed to, and I am afraid will yet live long' (Ambedkar, 1917, p. 21). In the making of the 
nationalist project in the nineteenth century, the economically deprived untouchable castes remained trapped in the double-bind of colonial administration and majoritarian nationalism, and the dawn of democracy has not been able to change that situation where, being torn everyday between poverty and embodied violence, Dalits are forced to suffer social ostracism silently. The continuity of such deeply embodied views not just affects rational thinking but also infrastructural changes, and the predominance of such embodied views serves as a reminder of the incompleteness of the nationmaking project: the haunting echo of Ambedkar's reminder of the Bahishkrut Bharat ('quarantined India') within the 'Parishkrut Bharat' (sacred India). Such a situation of doubleness continuously shapes the infrastructural concerns in a way that creates a sense of alienation for the marginalized 'others', a situation that was echoed earlier in Ambedkar's work Untouchables, or the children of India's ghetto (2014; originally 1989).

Can such frameworks of thinking (which are deeply embodied, hegemonic, and historically unfolded for generations) be countered by an absolute ignorance of conceptual training? Similarly, these questions of historical sedimentation and embodiment remind us of the impossibility of annihilation of the caste-system if caste-based differences and antagonism are held on to, even in an inverted political order, thereby foreclosing the central democratic ideal of 'equality'. Ambedkar was aware of such a haunting spectrality of caste and therefore identified it as essentially undemocratic since it takes inequality and hierarchy as the governing principle and even forecloses the possibility to do away with it:

One European solution was to respect the rights of others (because one thought one had rights; therefore, others too must have them), so that others respect our rights in turn; a certain reciprocity is assumed (never fully proved). This is where the problem crystallizes itself. This is about the so-called idea/l of democracy: We are all equal and therefore must be treated equally. (Ambedkar 1936 (2014), p. 172)

In the question of caste, this idea/l of democracy is not available in the thinking of a common society. Caste constitutes the thinking of society only in separatist terms. While the historically continuing hegemonic forms of Brahminical social organization come to be internalized as the only access to think identities, religion, and history, the continuity of such hegemonic framework continuously displaces the other interacting frameworks within histories and it is through such forms of displacements that caste survives with changing generations. It therefore, reminds us that without the annihilation of this organizing principle, embodied deeply within our imagination, the annihilation of caste remains impossible since it keeps reproducing similar discriminatory frameworks of thinking on which caste-system feeds. Thus, predetermined division of 'Savarna' and 'Dalit' in purely exclusionary and absolutist terms reminds us, paradoxically, of such reproduction of caste-based politics which it otherwise intends to destroy. This is a paradoxical problem that Jaaware (2001) too had identified as affecting the reading (as a form of consumption) of Marathi Dalit poetry that not only reduces the potentials of Dalit poetry (as politics) but also reinforces the caste-binaries in newer latent forms (pp. 264-280). Ambedkar was well aware of such possibilities of continuity of caste structure even within attempts to get rid of it, and thus for him a complete annihilation of it demanded a complete annihilation of the 
conceptual structures that enable its circulation, and the embodied ideas of Hinduism were one such breeding ground (Ambedkar, 1936). In his celebrated Annihilation of Caste wherein Ambedkar reminds us continuously that political and democratic reform cannot be asserted without social reform it becomes evident that he indirectly talks about the necessity of getting rid of the embodied ideas of caste hierarchy to ensure their annihilation from material forms of practice: '... let political reformers turn in any direction they like, they will find that in the making of a constitution, they cannot ignore the problem arising out of the prevailing social order' (Ibid, p. 178). For Ambedkar, caste forecloses the capacity to constitute a collective community based on equality and fraternity, and practicing a priori discriminations based on identifying 'Savarna' seems to continue paradoxically the same emphasis on 'varna'. I quote Ambedkar here:

The first question I ask is: Will the proletariat of India combine to bring about this revolution? What will move men to such an action? It seems to me that, other things being equal, the only thing that will move one man to take such an action is the feeling that other men with whom he is acting are actuated by feelings of equality and fraternity and - above all - of justice. Men will not join in a revolution for the equalisation of property unless they know that after the revolution is achieved they will be treated equally, and that there will be no discrimination of caste and creed. (Ibid, p. 182)

Whether one decides to emphasize on a politics focusing on people having-the-varna or lacking-the-varna the emphasis on 'varna' continues and so continues the separation of people based on the politics of 'varna.' In that way, one may even dismiss the contributions of Jotiba Phule and his attempts of empowering lower castes through education: to use Eleanor Zelliot's words, 'the first Dalit educator was not a Dalit, but is a Dalit hero' (Zelliot, 2016, p. 46). Doing away caste, I submit, essentially calls for rejecting any consideration of the question of varna. What I am proposing may be seen as utopian but my call is utopian in its etymological sense of a different place (ou topos, not place), and so was Ambedkar's in his call for a radical equality and annihilation of caste. Ambedkar had repeatedly asserted that the assurance of democracy must be the assurance proceeding from a much deeper foundation - namely, the mental attitude of the compatriots towards one another in their spirit of equality and fraternity (Ambedkar 1936, (2014), p. 183), and any discriminatory politics that relies on a priori exclusionary structures of identifying 'Savarna', or 'Dalit' seem to reflect a relation of antagonism (instead of brotherhood and equality) and therefore an inversion within counter-politics whereby caste and its reliance on 'varna' discrimination continue to live. Ambedkar was aware of such possibilities when he asserted:

The caste system prevents common activity ... One caste enjoys singing a hymn of hate against another caste as much as the Germans enjoyed singing their hymn of hate against the English during the last war. (Ibid, p. 191)

By keeping apart people of the same society into different irreconcilable segments caste stands exactly against what democracy stands for, and as such, for Ambedkar caste was by its essential nature 'anti-social.' Doing away with caste demands doing away all its conceptual registers, and attempts of annihilating caste that continue to rely 
on the memories of an old order cannot think of an entirely casteless future. Therefore, for Ambedkar, annihilating caste demanded an absolute overthrow of the conceptual structures (of Hinduism) on which caste breeds itself. One needs to realize that such an approach where the problem survives through deeply embodied conceptual structures cannot be addressed without changing the habits of conceptualization. That's why many scholars, in recent times, have repeatedly emphasized the necessity of changing the conceptual registers of thinking caste: As a problem of reading and interpretation (Ganguly, 2005), as a problem of everyday social (Guru and Sarukkai, 2012; 2019), as a problem of touch and touching (Jaaware 2019), to look for a politics beyond a politics of rage and revenge (Nagaraj, 2010), as a problem of equality (Kumar, 2015), and so on. One can therefore realize here briefly the ethico-political necessity for what Jaaware calls 'oublierring' or 'deliberate forgetting' (Jaaware 2019, pp. 13-15). Bringing in the subtle differences between Western ideas of 'society' (derived from 'socius' which stands for companion, follower, etc.) and the Indian 'samaj' (which also stands for caste, clan, community, etc.), Jaaware points at the innumerable contradictions that caste brings into the thinking of a common society: while caste is segmentalist (in the sense that it aims to cut apart), society aims at unifying all into one (Jaaware 2019, pp. 171-189). However, this is an intimate cut that caste brings in within the thinking of a common samaj: 'We interact with but will not relate to that other samaj. The members of that samaj are not from ours' (Ibid, p. 171). Thus, at the unavailability of a common society (since to take the fourfold division as unavoidable 'law' also expects the constitution of four different societies), to identify oneself with a common society demands the invention of an idea of a common society that one may identify with, and this is what Jaaware decides to call sociability (Ibid, p. 172). With the persistence of caste, not only the idea/l of a common society remains a foreclosure, practicing different forms of autonomous individual sociability also remains a prohibition. In other words, the persistence of the embodied idea of caste within a democratic system operates as mutually contradictory since neither the individual nor a common singular unity can survive under the caste structure; the latter must replace the former according to its ways of hierarchical social organization and as such equality remains impossibility.

The continuity of such deeply embodied perspectives, shaped by the historical sedimentation of the hegemonic Brahminical principles of organizing (as discussed in the first section), therefore shapes the reading habits as well, preventing thereby from recognizing the multiple 'other' voices of history and community. In such context, epistemological practices too cannot be seen as disembodied, and the divisions of 'theory' and 'practice' in exclusive terms remain part of such layered, ambiguous, embodied problems of reading habits. A reading of caste premising on pragmatic empiricism that rejects 'theory' or 'theorization' and why such reading needs to be questioned to be able to reshape the 'doing' of social science as well as the 'doing' of theory is a point that was already explored by Guru and Sarukkai in The cracked mirror. In rereading (and reevaluating) Guru and Sarukkai's views on the 'doing' of theory some of the points (including few objections) that Kaviraj makes in his response require a serious engagement and can offer us to rethink the very acts of reading a phenomenon like caste. Kaviraj (2013) reminds how in the last few decades a new trend of study, premised upon empirical facts, has come to dominate the reading of caste within what is categorized as 'social science'. He reflects very briefly on the historical making of such epistemological shift (Ibid, pp 380-381): 
A new history of this kind requires, as many observers have noted, a new language of science. It is not surprising that before independence, this form of modern knowledge about Indian society was produced primarily by European scholars, and by Indians trained in the West, following their conceptual and argumentative lead. As the base of social sciences expanded, this relation was slowly reversed ... The immense variety of social life in India, fundamentally different from life forms of European modernity that were captured by 'social theory,' led to an invitation to innovative in social science. Serious study of a tribal village, a Dalit neighborhood, a Brahminical intellectual practice, and business systems of the bania (merchant caste) immediately presented evidence of historical difference and consequently stretched the boundaries of the empirical universe of facts for social science knowledge. Accumulation of evidence of a social universe utterly at variance with the European gave rise to discomfort about theoretical languages in which this knowledge was gathered.

This discomfort or distrust of 'theory' versus a ready acceptance of empirical fact as 'objective truth' also takes us back to the same question of deep embodiment and historical sedimentation. Apart from caste, this antagonism can be traced also within feminism and science studies, which has been addressed already in nuanced ways by standpoint theories. ${ }^{7}$ In philosophical lineage, this divide takes us back to the debate between 'idea' and 'matter' that can take us long back to Greek philosophical debates and remains something that is still recurring continuously in different forms of epistemological engagements. We can understand that such concerns about 'reading' caste remain always entangled with many similar concerns that operate not only beyond caste but also offer (and is required essentially) possibilities of engaging with larger intersectionalities that 'reading' caste can offer: For example, concerns such as corporeality, experience and epistemology, which hold unavoidable significance for engagement with other areas of discrimination such as sex-gender systems or race. In the case of caste, as Kaviraj briefly hints in the extract quoted above, there is a historical paradox at work in shaping such empirical domination within 'social sciences'. While the attempt to 'scientifically' and 'objectively' study culturally different communities formed the core of colonial anthropology and ethnography, a similar tendency persisted in the uncritical methodological hailing of empirical postcolonial anthropology and its attempt to (re-)assert socio-cultural difference, while on the other hand the same call for decolonizing epistemologies are called equally uncritically in the rejection of 'theory' as western. This constitutes a paradoxical epistemological problem within the doing of social sciences in India wherein on one hand under the uncritical call for decolonizing epistemological practices, 'theory' is rejected as overtly western and not applicable in Indian context, whereas on the other hand anthropological and ethnographical studies continue similar methodological empirical frameworks that premise on the colonial model of asserting difference. In the context of caste, such uncritical reliance on the existing empirical methodologies as promising 'truth' (like a similar uncritical rejection of 'theory' as western, illusionary or incapable) paradoxically reconstitute the same colonial lens of reading caste as a symptom of socio-cultural difference, and as a result of which despite changing times the conceptual and

${ }^{7}$ This has already been attempted by Anirban Das in his paper "Caste and Gender: Generalities of Experience" where he talks about what feminist standpoint theories can offer for theorizing dalit experience. 
functional registers of caste don't seem to change much. Such questions, therefore, remind us again how the problem of embodiment, as we see in the question of caste, functions not just in the domain of social, political, religious, and corporeal practices but also includes the question of epistemological practice. Since 'lived experience' is a major area of debate concerning such epistemological divisions, it becomes necessary to reexamine the problems of addressing the question of 'experience' (which again, if it has to be addressed for communication, must be done through language as a 'concept') with relation to conceptual boundaries like that of inside/outside, spectatorial/lived, or ontological/epistemological which has also characterized the division of Savarna versus Dalit, academia versus activism, for many generations as if like an unbridgeable binary. In the question of caste, such examination of 'experience' calls for a specificity (historical, theological, political, and ontological) that refuses to be considered in terms of the generality of experience. However, the problem emerges with a paradoxical (non-)positionality: can that exclusive specificity of 'experience,' the immediate corporeal experience accessible only to the body at the moment of experiencing, be reflected without resorting to some form of generality in acts of conceptualizing experience even by the experiencer when s/he is no longer experiencing the corporeal experience they had experienced earlier? In other words, is not experience engaged with as an 'idea' when the ontological experience is being attempted to be reflected within epistemological or linguistic attempts? What kind of 'experience' is at work in such forms of understanding, recording, and communicating? Are such acts empirical or theoretical? These questions, haunting the question of 'experience' within caste, also resonate with other domains of 'experience': two most obvious ones are the question of gender and race difference (both of which too, like caste, claim their ontological specificity). Pushing in the same way, in her response to The cracked mirror, Rajeswari Sunder Rajan (2013) calls for the necessity to engage with the castequestion 'theoretically', not only to be able to keep extending the theorizing of experience but also the experiencing of theory. One can recall that such questions of 'theory' and 'practice', specifically concerning the question of experience, apart from the questions of race and gender difference, also formed a major area of debate within Marxism. As one small example, one can turn towards the chapter 'On the materialist dialectic' where Althusser (2005) points out very poignantly about the necessity of making a Marxist theory out of Marxist practice (not just the opposite direction), and the difference between any casual knowing and the making of a rigorous epistemology out of an existing practice that can change or transform the existing practice ${ }^{8}$ ( pp. 162171). I submit that acts of theorizing caste and Dalit experience too need to make such epistemological conditions for connecting with an-other's experience. One needs to remember here that the task of theorizing is not merely a task of 'lisping imitation' of existing concepts (Kaviraj 2013, p. 381), rather a rigorous and continuous extension of acts of conceptualization (be it experience, practice, or the concept itself). The task of theorizing caste continuously pushes us to reconsider what it means to 'experience' a life burdened with a continuous sense of alienation? Are not such experiences shared by many people in different parts of the world (despite the specificities of context) clubbed under terms like 'minority' or 'subaltern'? Isn't it a necessity to realize that pushing the theorizing of Dalit life, and/or calls for annihilation of caste can offer

${ }^{8}$ In fact, throughout the book Althusser analyzes such debates within Marxism concerning theory/praxis, ideal/material, epistemological/ontological divisions. For further details, also see the chapter "Marxism and Humanism" from the book For Marx. 
newer forms of expression for resistance and solidarity in such 'other' registers of oppression and discriminations, just like theorizing Dalit lives has gathered from other contexts (black feminism, Marxism, negritude, etc.) both inspiration and expression for resistance and solidarity? This again reminds us of the binding capacity of language that enables one to conceptually connect with an-other's experience in an-other context, which takes us to the aesthetic functions of language in the bringing together of ontology and meaning. One can here turn back to Baumgarten's (1954) views on aesthetic as proposed in his Reflections of Poetry, in the Greek sense of the word aisthanomai (to perceive), which was always directly linked with sensory experience and therefore never entirely detached from the materiality of the body. Using this Anirban Das reminds that though in many works, as in Terry Eagleton's The ideology of the aesthetic - where the body is treated as a resource for a 'long articulate rebellion against the tyranny of the theoretical' (Eagleton 1990, p. 13) - yet such articulations fail to realize that if one remains undecided over such a possibility for the 'body' as material, the body as metaphor still remains operative as a contingent resource for figuring a domain beyond the calculations of reason (Das, 2012, p. 125). The theoretical is not just an abstraction against which the material body is to be posed; the material body too is a theoretical tool for conceptualizing / communicating the materiality of (corporeal) experience in language. I submit that the aesthetic reminds us continuously of such capacity of the corporeal being (in its bound togetherness by the commonality of language): for becoming, sharing, and solidarity. It is to hint at such possibilities of communication and solidarities that Homi. K. Bhaba (2019) turns towards a section from Toni Morrison's Home (2013):

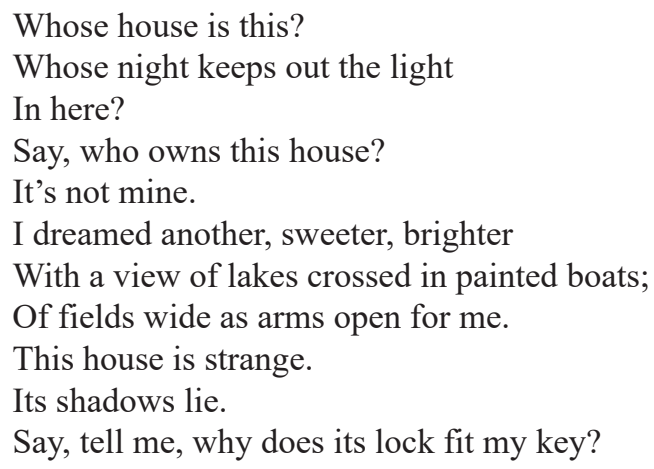

These lines, as Bhaba (2019) stresses, identify directly with the experience of being a Dalit in a casteist nation, and much more; to anyone's experience of being alienated like a foreigner in one's own home. I quote:

This dark house of the nation's history is not mine... It has dispossessed me and discriminated against me; it has unhomed my history and darkened my presence. I am untouchable, I am enslaved, I am trafficked, I am lynched. This house is strange ... And yet, say, tell me, why does its lock fit my key? [Italics in original] (Ibid, p. 229)

This sense of alienation is what the caste-based organizing of samaj (and its canons and histories) brings for the Dalit. As pointed by Jaaware (2001, pp. 262-64), this is 
an intimate cut which goes back as early as the mimansa traditions (one of the early heterodox systems of Indian philsophy): while in those times the cut constituted in terms of the reading of Vedas (the fourth varna is inside the samaj but outside its recognition and privileges), in postcoloniality the cut operates in terms of claiming democratic rights. This reminds us therefore, how the problem of doubleness of democracy, in the context of India and caste, has settled historically through generations and continues to organize the thinking of identity and society in terms of a dominant framework of majoritarian Hindu 'nation.'

\section{Aesthetic Education in the Training of Imagination: the Urgency for Realizing the Value of Equality}

The caste question, therefore, forces us to reconsider the very infrastructural question of postcoloniality and its unfulfilled promise of equality, reminding us continuously of the alienation of the 'other' of the nation (the poor, Dalits, women, and so on). Such questions therefore bind us together within a shared sense of similar experiences (though the contextual specificities may differ) of betrayal, humiliation, and discrimination that democracy failed to infrastructurally deliver in different contexts. Exploring such concerns onto-epistemologically therefore creates possibilities for critical dialogue and interactions between otherwise dispersed experiences. Such dialogues remind us of the necessity of reading together, to rethink what 'theories' of one specific context of experience can offer in an-other's context; what the reading together (despite their specific differences) of Ambedkar, Marx, Arendt, or Agamben can offer in critiquing the historical exclusions and dispersed bio-politics of modern 'nation'. As Veena Das (2019) reminds us using Didier Fassin's views on the politics of life:

...the notion of life splits the human into two domains - that of physical and biological life that man has in common with animals, and of political life that separates man from animals and gives him a unique place in the scheme of things. But does society offer the same possibilities for engaging in politics to all sections? What about women, the poor and the dispossessed? Although there are important differences in the theoretical positions of these three authors, there is a general line of thought that postulates that the power of the exception is invested in the sovereign that can strip the lives of those living in abject conditions [...] to bare life that can be taken away by the mere will of the sovereign. (Das, 2019, pp. 77-78)

While this reminds us continuously of the precariousness of life, it also calls for the necessity to engage more seriously with such concerns in ways that can enable not only epistemological but infrastructural changes by changing the habits of everyday thinking. Such dialogues remind us continuously not only of the specificities separating one from other but also the generalities of experience through which one can relate with the other thereby enabling forms of solidarity. Though in the individual specificities of experience one's experience remains always limited within one's corporeal self, yet it is the generalities of such experiences that enable their communication with each-other.

The infrastructural question of postcoloniality, that Spivak (2012) stresses in her book An aesthetic education in the era of globalization, when seen from the 
perspective of caste, makes us realize the hauntological echoes of past within the present, which remind us not only how hegemonic principles of organizing keeps on imposing dominant versions of history and becoming as the 'normative', but also how such organizing principles shape the habits of reading and conceptualization. We can recall here her point that the British and the caste-Hindu reformers only concentrated on the visible violence of sati and passed a widow remarriage law without any infrastructural involvement. In the question of caste, the only limited infrastructural option that was available to Ambedkar at the time of decolonization was that of ensuring some reservations and legal rights to safeguard the Dalits and backward sections from suffering material deprivations and violence that an otherwise majoritarian upper-caste Hindu society and its embodied casteism could have practised, and the continuity of caste discrimination and violence today proves that at every juncture. This reminds us continuously of the problem of the doubleness of history through which caste survived with modernity and decolonization. As Sekhar Bandyopadhyay (2004) reminds, the constitution guaranteed special privileges to Dalits as long as they remained Hindu; however fallacious this policy may be, its fundamentals remain unchanged even today. So, the enjoyment of privileges of affirmative action - which creates the expectation of Dalit empowerment through the process of Mandalisation ${ }^{9}$ - remains conditional upon the acceptance of the teleological taxonomy of the Indian nation-state (Bandyopadhyay p. 43). However, as emphasized already, Ambedkar's actual ideal was democracy and that is where we have failed to cultivate the values of equality properly. As Spivak (2019) reminds us in the context of capital, the 'value' for Marx was essentially abstract, and therefore had the potentiality for a revolutionto-come, provided its transformative and volatile capacities were realized properly by the proletariat. However, the problem was with Engels' translation of Marx and the reductionism operating there: the decisive cuts through which the folded-togetherness of value was reduced within a decisive empiricism of exchange value only, and that is where the history of the left rose and fell. I humbly submit, similar is the problem of translatability of the 'value' of democracy, between what Ambedkar had conceptualized and what instead came to us through the lens of the embodied majoritarian Hindu nationalism. As Spivak reminds,

Real change must be epistemic rather than merely epistemological, home as well as school... all these efforts, however carefully undertaken by the engaged intellectual,... is offset by the development of ethical and epistemic semiosis in the subaltern household, cradled in an often traumatic childrearing which is so deeply involved in the lessons of millennial class apartheid and gender division that it continuously creates the problem that one is trying to solve. (Spivak 2012, p. 132)

\footnotetext{
${ }^{9}$ This refers to the Mandal Commission's Report of 1980 which aimed to empower the backward castes by ensuring certain reservation policies for them. However, the paradoxical side of this reservation was also the legal identification of 'scheduled castes' and 'other backward castes', which ironically also enabled a legalization of caste differences. Added to that was also the point, as highlighted by Sekhar Bandopadhyay (2004), that the caste-based reservations are applicable as long as one is a Hindu, thereby further legitimizing the linking of Hinduism and Caste-system (Scheduled Caste Order of 1950 says: 'No person who professes a religion different from the Hindu religion shall be deemed to be a member of a Scheduled Caste.').
} 
If ethics is conceptualized as a problem of relation rather than a problem of knowledge, it is not enough to build purely empirical databases; rather what is required is an act of relation and suspension, and to perform that one needs a training of the imagination to realize the suspending potentials of imagination. One should be able to think of one's self from an-other's perspective, or in other words, to lose one's self in an-other's self. This is a transformative capacity that doesn't foreclose itself according to any hegemonic framework. Instead, it is a role that one participates in not to control but to lose oneself:

When one decides to speak of double binds and aporias, one is haunted by the ghost of the undecidable in every decision ... Again, it must be insisted that this is the condition of possibility of deciding. In the aporia or the double bind, to decide is the burden of responsibility. The typecase of the ethical sentiment is regret, not self-congratulation... (Ibid, pp. 104-5)

...Any trick to train them into a mental habit of othering rather than merely provide them with tools to describe... in the othering of the self and coming as close as possible to accessing the other as the self. (Ibid, pp. 112-13)

I submit this is the language of democracy which we have failed to translate: to understand the self in terms of the other, to entail the ethical within the political. If caste is the embodiment of a hegemonic idea then the possibility of its 'annihilation' lies in crossing over the double-bind within which we are trapped today, and herein comes the necessity of stressing on a conscious training of the imagination in the habits of democracy. It is towards such directions, among other possible routes, that I stress the importance of aesthetic education for the training of the imagination. Standing at a juncture where we are witnessing the rise of another wave of majoritarian Hindu nationalism; where newer forms of caste discriminations recur every day, where laws don't stand for ensuring the values of equality, such stress on the onto-epistemological necessity for the training of imagination in the language and values of democracy acquires an ethico-political necessity to make grounds for a futurity-to-come that realizes the values of democratic equality. Otherwise, 'In the absence of a people educated in the habits of democracy, there are no constraints upon the vanguard (Ibid, p. 133).

\section{References}

Abraham, Joshil K. and Judith, Misrahi-Barak. (Eds.) (2016). Dalit literatures in India. London/ New York: Routledge.

Althusser, Louis. (2005). For Marx (trans. B. Brewster). London/New York: Verso.

Ambedkar, B. R. (1917). Castes in India: their mechanism, genesis and development. Indian Antiquary, XLI.

- (2014). Untouchables or the children of India's ghetto (originally 1989). In P. T. Borale, B. D. Bhadke, S. S. Rege, and Daya Pawar (Eds.), Dr. Babasaheb Ambedkar: writings and speeches, vol. 5, compiled by Vasant Moon (pp. 3-112). New Delhi: Dr. Ambedkar Foundation.

- (2011). The Buddha and His Dhamma (originally 1956). In A. Singh Rathore and A. Verma (Eds.), The Buddha and His Dhamma: a critical edition. New Dehi: Oxford University Press. 
- (2014). The annihilation of caste (originally 1936). In S. Anand (Ed.), Annihilation of caste: the annotated critical edition (pp. 144-282). London/New York: Verso.

Bandyopadhyay, Sekhar. (1997). Caste, protest and identity in colonial India: the Namasudras of Bengal, 1872-1947. Cornwall: Curzon Press.

- (2004). Caste, culture and hegemony: social domination in colonial Bengal. New Delhi/ London: Sage Publications.

Bandopadhyay, Sumanta. (2008). Unish shotoker Kolkata o Saraswatir itor sontan (Nineteenth Century Calcutta and the Lowly Children of Saraswati). Kolkata: Anustup.

Baumgarten, Alexander Gottlieb. (1954). Reflections of poetry (trans. K. Aschenbrenner and W. B. Holther). Berkeley/Los Angeles: University of California Press.

Bhaba, Homi K. (2019). The burdened life: Ambedkar, Arendt and the perplexity of rights. In V. Rodrigues (Ed.), Conversations with Ambedkar: 10 Ambedkar Memorial Lectures (pp. 228-248). New Delhi: Ambedkar University and Tulika Books.

Bhattacharya, Ramkrishna. (2011). Studies on the Cārvāka/Lokāyata. London/New York/ NewDelhi: Anthem Press.

Chatterjee, Partha. (1993). The nation and its fragments: colonial and postcolonial histories. New Jersey: Princeton University Press.

Chattopadhyay, Debiprasad. (1959). Lokayata: a study in ancient Indian materialism. New Delhi: People's Publishing House.

Chaudhuri, Rosinka. (2012). Freedom and beef steaks: colonial Calcutta culture. New Delhi: Orient BlackSwan.

Colebrooke, H. T. (1795). On the duties of a faithful Hindu widow. Asiatick Researches, Issue 4, 109-19.

- (1858). Essays on the religion and philosophy of the Hindus. London: Williams \& Norgate.

Das, Anirban. (2012). Aestheticizing law into justice: the fetus in a divided planet. In É. Balibar, S. Mezzadra, and R. Samaddar (Eds.), The borders of justice (pp. 123-144). Philadelphia: Temple University Press.

- (2017). Sexual difference in a different religiosity: writing the nation in "my life". philoSOPHIA, 7(1), 23-44.

- (2019). Caste and gender: generalities of experience. Sanglap: Journal of Literary and Cultural Inquiry, 6(1), 99-111.

Das, Veena. (2019). Citizenship as a claim, or stories of dwelling and belonging among the urban poor. In V. Rodrigues (Ed.), Conversations with Ambedkar: 10 Ambedkar Memorial Lectures (pp. 77-100). New Delhi: Ambedkar University and Tulika Books.

Dutta, Akshay Kumar. (1871). The religious sects of India (Bharotborshiyo Upashok Somprodaye). Calcutta: Sanskrit Press.

Eagleton, Terry. (1990). The ideology of the aesthetic. Oxford: Blackwell Publishers.

Figueira, Dorothy M. (2002). Aryans, Jews, Brahmins: theorizing authority through myths of identity. Albany: State University of New York Press.

Flora, Giuseppe. (1993). The evolution of positivism in Bengal: Jogendra Chandra Ghosh, Bankimchandra Chattopadhyay, Benoy Kumar Sarkar. Supplemento n. 75 agli Annali, Volume 53. Napoli: Istituto Universitario Orientale.

Ganguly, Debjani. (2005). Caste, colonialism and counter-modernity: notes on a postcolonial hermeneutics of caste. London/New York: Routledge.

Ghose, Girish Chunder. (1912). Ram Doolal Dey, the Bengali millionaire. In M. Ghosh (Ed.), Selections from the writings of Girish Chunder Ghose (pp. 1-43). Calcutta: The Indian Daily News Press. 
Ghosh, Benoy. (Ed.) (1955). Samayik Patre Banglar Samajchitro: 1840-1905, Volume 1. Calcutta: Bengal Publishers.

Guru, Gopal and Sundar Sarukkai. (2012). The cracked mirror: an Indian debate on experience and theory. New Delhi: Oxford University Press.

- (2019). Experience, caste, and the everyday social. New Delhi: Oxford University Press.

Jaaware, Aniket. (2001). Eating, and eating with the dalit: a re-consideration touching upon Marathi poetry. In K. Satchidanandan (Ed.), Indian poetry: modernism and after (pp. 262193). New Delhi: Sahitya Akademi.

- (2019). Practicing caste: on touching and not touching. New York: Fordham University Press.

Kaviraj, Sudipta. (2003). The two histories of literary culture in Bengal. In S. Pollock (Ed.), Literary cultures in history: reconstructions from South Asia (pp. 503-566). Berkley, Los Angeles/London: University of California Press.

- (2013). Why is the mirror cracked? Comparative Studies of South Asia, Africa and the Middle East, 33(3), 380-391.

Kumar, Aishwary. (2015). Radical equality: Ambedkar, Gandhi, and the risk of democracy. California: Stanford University Press.

Max Muller, Friedrich. (1899). The six systems of Indian philosophy. London/Bombay: Longmans, Green, And Co.

Mukherjee, S. N. (1977). Calcutta: myths and history. Calcutta: Subarnarekha.

Nagaraj, D. R. (2010). The flaming feet: a study of the Dalit movement in India. Ranikhet: Permanent Black.

Satyanarayana, K. and Susie Tharu. (Eds.) (2013). The exercise of freedom: an introduction to Dalit writing. New Delhi: Navayana.

Sinha, Pradip. (1965). Nineteenth century Bengal: aspects of social history. Calcutta: Firma K. L. Mukhopadhyay.

Spivak, Gayatri Chakravorty. (2012). An aesthetic education in the era of globalization. Cambridge/Massachusetts/London: Harvard University Press.

Sunder Rajan, Rajeswari. (2013). Theory in the mirror of caste. Comparative Studies of South Asia, Africa and the Middle East, 33(3), 391-397.

Thapar, Romila. (2019). Multiple theories about the 'Aryan'. In R. Thapar, M. Witzel, J. Menon, $\mathrm{K}$. Friese and R. Khan (Eds.), Which of us are Aryans? rethinking the concept of our origins (pp. 30-93). New Delhi: Aleph Book Company.

Zelliot, Eleanor. (2016). Dalit initiatives in education, 1880-1992. In P. V. Rao (Ed.), New perspesctives in the history of Indian education (pp. 45-67). New Delhi: Orient BlackSwan. 